http://kitaibelia.unideb.hu/

ISSN 2064-4507 (Online) • ISSN 1219-9672 (Print)

(C) 2016, Department of Botany, University of Debrecen, Hungary

21 (2): 198-206.; 2016

DOI: $10.17542 /$ kit.21.198

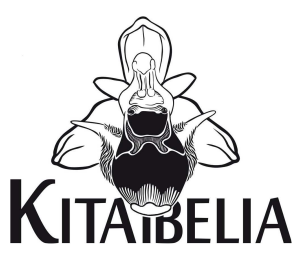

\title{
A martonvásári kastélypark mohaflórája
}

\author{
NAGY Zoltán ${ }^{1 *}$, MAJLÁTH Imre ${ }^{1}$, MolNÁR Marcell ${ }^{1} \&$ ERZBERGER Peter ${ }^{2}$ \\ (1) Magyar Tudományos Akadémia Agrártudományi Kutatóközpont Mezőgazdasági Intézet, \\ H-2462 Martonvásár, Brunszviku. 2.; *zoltan.nagy.biol@gmail.com \\ (2) Belziger Straße 37, D-10823 Berlin, Németország
}

\section{Bryofloristical study in the Brunszvik manor park in Martonvásár, Hungary}

Abstract - This is the first bryofloristic study in the Martonvásár manor park. In our survey in 2015, 56 species (6 liverworts and 50 mosses) were found in the park. Most of them are considered to be common in Hungary, but an endangered (Eurhynchium speciosum), a vulnerable (Orthotrichum patens) and five near-threatened species (Aphanorrhegma patens, Orthotrichum obtusifolium, Orthotrichum pumilum, Pseudocrossidium revolutum, Riccia cavernosa) were also found. These results point out the nature conservation value of the manor park.

Keywords: bryoflora, floristics, manor park, anthropogenic habitat

Összefoglalás - A martonvásári kastélypark mohaflorisztikai felmérését 2015-ben végeztük el, korábban nem történtek ilyen átfogó vizsgálatok a park területén. Munkánk során 56 fajt találtunk (6 májmoha és 50 lombosmoha). A fajok többsége közönséges, de találtunk természetvédelmi szempontból figyelmet érdemlő fajokat is. Az Eurhynchium speciosum veszélyeztetett magyarországi vörös listás besorolású faj. Ezen kívül előkerült még egy sérülékeny státuszú faj (Orthotrichum patens) és öt veszélyeztetettséghez közel álló (Aphanorrhegma patens, Orthotrichum obtusifolium, Orthotrichum pumilum, Pseudocrossidium revolutum, Riccia cavernosa). Ezek az eredmények is megerősítik a park természetvédelmi értékét.

Kulcsszavak: mohaflóra, florisztika, kastélypark, antropogén élőhely

\section{Bevezetés}

A magyarországi kastélyparkok, arborétumok és botanikus kertek mohaflorisztikai kutatása bár nem olyan népszerû, mint a természetes élőhelyek vizsgálata, mégis több botanikus foglalkozott ezeknek az antropogén területeknek a bryológiai vizsgálatával. Az 1940-es évek végén Boros Ádám a szarvasi Pepi-kertből 27 mohafajt mutatott ki (apud VAjDA 1954). A Vácrátóti Botanikus Kert vizsgálatakor 102 faj került elő (VAJDA 1954). Szigligeti Arborétumban 48 fajt találtak (VAJDA 1968). A Zirci Arborétum mohaflóráját először Galambos István, majd Szűcs Péter vizsgálta, itt 64 fajt írtak le (GaLAmBos 1992, Szứcs 2013). A Soproni Botanikus Kertből 56 taxon került leírásra (IGMÁNDY 1949, SzỨcs 2008). Az Agostyáni Arborétumból pedig 37 mohafaj került elő (SzŰ́cs 2009).

A martonvásári kastélypark az 1750-es évektől kezdődően alakult ki a Brunszvik család letelepedésével. Tőlük származnak azok a korabeli feljegyzések is, melyek szerint a terület korábban erősen vízjárta, mocsaras volt (РÓKA 1978). A mocsár lecsapolása után, a tó kialakítása, és környezetének erdősítése során, az elismert kertépítő, Nebbien tervei alapján angol- 
kertté alakították a parkot. Eredeti kiterjedése meghaladta a 200 ha-t. A park 70 ha-nyi magterülete, 1953 óta országos jelentőségű természetvédelmi terület. Bár az elmúlt századokban több ismert botanikus, mint Kitaibel Pál, Boros Ádám, Jávorka Sándor, Horvát Adolf Olivér és tanítványa (KEVEY 1979 és 1987, MANNINGER 1989) is járt a területen, botanikai feltártsága elsősorban az edényes flórára szorítkozik (KEVEY 1987, KEVEY et al. 2016), részletes bryológiai felmérés nem történt. Boros Ádám kétszer jegyzett fel a parkból és annak közeléből mohafajokat 1946-ben és 1959-ben (Leskea polycarpa-t és Barbula fallax-ot (mai elfogadott neve Didymodon fallax) (BoRos 1915-1971). Munkánk célja volt, hogy részletesen dokumentáljuk a kastélypark mohaflóráját.

\section{Anyag és módszer}

A terepi gyűjtés és megfigyelés 2015 júliusa és decembere között zajlott változó gyakorisággal, 2015. október 17-én egy intenzív területbejárás során került begyưjtésre a legtöbb faj. A mohák azonosítása CASAS et al. (2006, 2009), ORBÁN \& VAJDA (1983) és SMITH (2004) munkái alapján történt. A mohák nevezéktana és magyarországi vörös listás besorolása PAPP et al. (2010) munkáját követik, kivéve a Syntrichia nemzetséget, ahol HILL et al. (2006) nomenklatúráját követtük. A begyüjtött példányok Nagy Zoltán és Erzberger Peter herbáriumában kerültek elhelyezésre. A felsorolásban szereplő florisztikai adatok a Középeurópai flóratérképezési rendszer alapján a 8678/4 számú kvadráthoz tartoznak. A gyakorisági jellemzés a következők szerint történt: ritka: 1-2 helyen találtuk meg a fajt a park területén, gyakori: 3-10 helyen találtuk meg, nagyon gyakori: tíznél több helyen található meg az adott faj. A lokalitások megállapítását az alábbiak szerint végeztük: élő és korhadó fán élő fajoknál egy fát, talajon, betonon és köveken élő fajoknál pedig azon mohagyepeket amik $50 \mathrm{~cm}$-nél közelebb vannak egymáshoz tekintettünk egy lokalitásnak.

A bemutatott térkép és a terület georeferálása a Quantum GIS 2.2.0 (Valmiera) nyílt forráskódú térinformatikai szoftver segítségével készült el (QGIS Development Team. 2014).

\section{A kutatási terület ismertetése}

Martonvásári kastélypark az Alföldön, a Mezőföld északi részén helyezkedik el, 120-125 m tengerszint feletti magasságban. Klímája mérsékelten meleg-száraz, 30 éves átlagok alapján az éves csapadékmennyiség $560 \mathrm{~mm}$, az évi átlagos középhőmérséklet $10,6^{\circ} \mathrm{C}$. A park talaja mészlepedékes csernozjom, a patak környéki erdővel borított részeken öntés erdőtalaj képződött a löszös, homokos hordalékon (ÁDÁm et al. 1959). A park területét az 1. ábrán látható térkép szemlélteti. A kastélypark teljes területe 70 ha, mely két nagyobb részre osztható. $\mathrm{Az}$ északi részen található a kastély és a modern építésű akadémiai épületek nagy része. Itt helyezkedik el a tó, nagy kiterjedésű gondozott gyepek, tölgy-kőris-szil ligeterdők, valamint kisebb vegyes facsoportok (platán, fenyő, mocsári ciprus) által körülvéve. A park déli részét mezőgazdasági területek, és a hozzákapcsolódó épületek (géptelep) uralják. Szegélyükben két vadgesztenyékből álló facsoport színesíti a tájat.

Négy jelentősen különböző élőhelytípust különíthetünk el a parkon belül: keményfaliget, gyep, szántóföld valamint az épületek és környezetük (utak, járdák, betonfelületek, aszfalt). A tölgy-kőris-szil liget az 1800-as években jött létre mesterséges telepítéssel, de azóta fajgazdag és természetszerű erdőtársulássá fejlődött, melynek pontos cönológiai besorolása: Scillo vindobonensis-Ulmetum (KEVEY in BORHIDI \& KEVEY 1996). A ligeterdőn kívüli élőhelyek jellegtelen, bolygatott és ruderális gyepek. A park területén keresztül folyik a Szent Lászlópatak, ami a park tavát táplálja. Botanikai szempontból jelentéktelen, mert a keményfa ligeterdőn kívül más jelentősebb vízhez kötődő élőhelyet nem találunk a park területén, se a patakban, se a tóban. Ennek oka lehet a patak szélsőséges vízjárása. Száraz években sokszor 
kiapad a patak. Jelenléte mégis meghatározó, hiszen befolyásolja a park vízellátottságát, ezáltal mezo-és mikroklímáját. Fontos megemlíteni, hogy az Eurhynchium speciosum élőhelye az egykori vízimalom romjainál alakult ki. Ez egy mesterséges meder, a „malom patak”, mészkövekkel kirakott szakasza, mely a tavat köti össze a Szent-László patak főmedrével. Vízjárása nagyon szélsőséges ezért meglepő élőhelye ennek a nem túl gyakori fajnak.

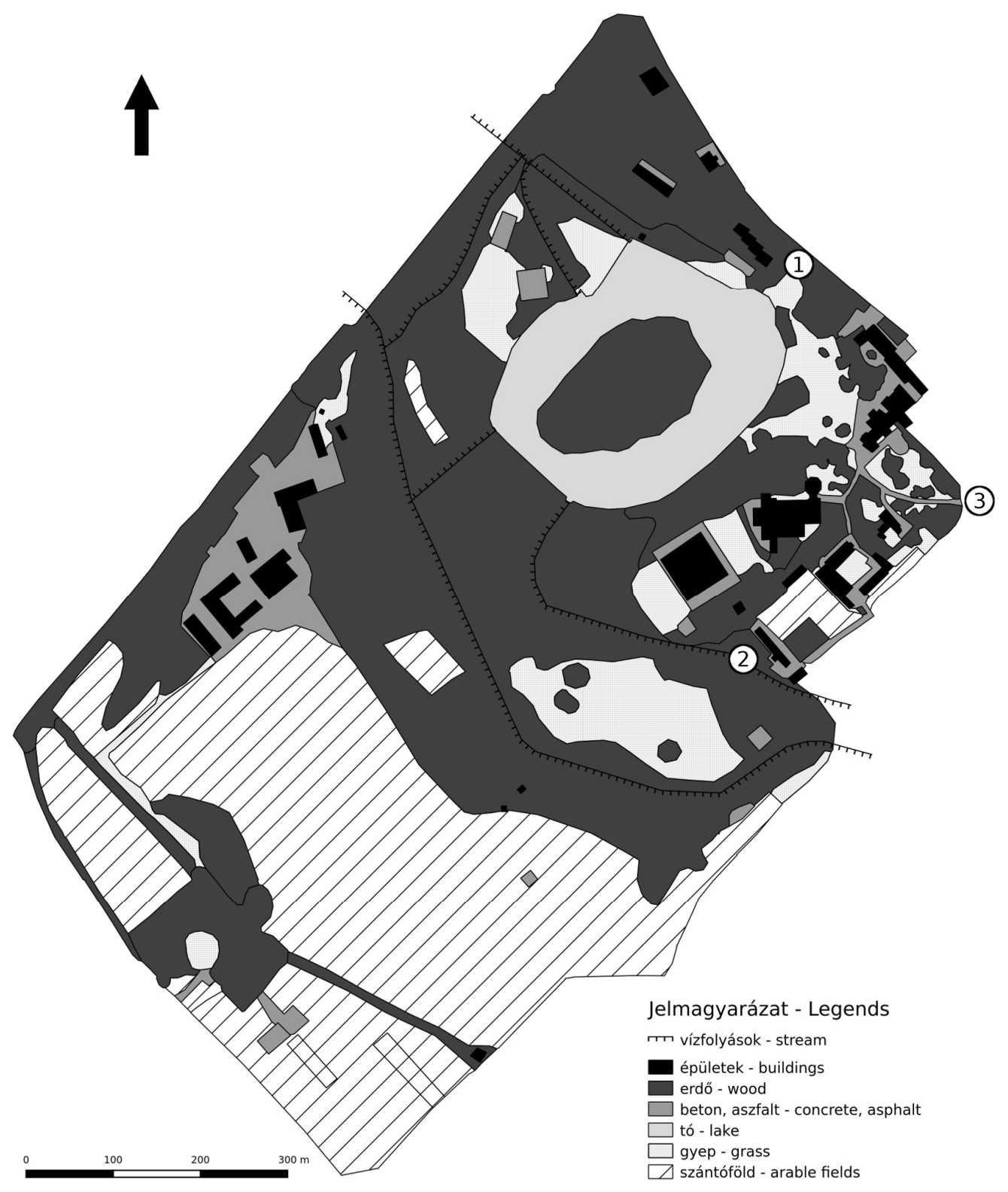

1. ábra. A martonvásári kastélypark sematikus térképe. A nyíl az északi égtájat jelöli. Jelzett pontok: 1) kőhíd, 2) vízimalom rom, 3) a park főbejárata

Fig. 1. Schematic map of Brunszvik manor park in Martonvásár. The arrow points towards North. Marked points: 1) stone bridge, 2) ruins of a watermill, 3) main entrance of the park 


\section{Eredmények}

A park mohaflórájának jellemzése

Ebben a leírásban a leggyakrabban előforduló fajokra szeretnénk kitérni. Az egyes fajok jellemzését az enumerációban részleteztük. A zárt keményfa ligetekben az uralkodó mohafajok a talajon a Brachythecium salebrosum és B. rutabulum. Kéreglakók közül még jelentős az Orthotrichum nemzetség, a leggyakoribb fajok az $O$. affine és 0 . speciosum, más fajok kisebb gyakorisággal vannak jelen, jelentősebb kéreglakó még a Homalothecium sericeum és Platygyrium repens. Az erdőszélek magányos fáin legtömegesebb faj a Leskea polycarpa, mellette Syntrichia papillosa-t, $S$. virescens-t és Bryum moravicum-ot találunk.

A gyepek mohaflórája nagyon szegényes. A leggyakoribb fajok Brachythecium rutabulum, Eurhynchium hians és Calliergonella cuspidata. A fák közötti, árnyékos, nedvesebb helyeken a Plagiomnium undulatum jelenik meg. A Vöröskúti-rét napos, de nedvesebb foltjain Drepanocladus aduncus él.

A szántóföldi területeken a leggyakoribb fajok a Bryum argenteum, Barbula convoluta, Pohlia melanodon, Phascum cuspidatum.

A park területén található egy a 19. században mészkőből épített kőhíd. Csak itt volt megtalálható, de nagy tömegben a Pseudocrossidium revolutum, mellette Bryoerythrophyllum recurvirostrum, Bryum caespiticium, Leskea polycarpa, Tortula muralis, Schistidium crassipilum és Hypnum cupressiforme volt még jelen.

Az emberi tevékenység a park területének vegetációjára jelentős hatással van. Nagy területű kezelt gyepek, jelentős beton és aszfalt felületek, nagy kiterjedésű épületek, üvegházak vannak a parkban. A beton és aszfalt felületek gyakori fajai: Amblystegium serpens, Barbula unguiculata, Bryum argenteum, Orthotrichum diaphanum, Tortula muralis. Az árnyékos tetőkön Syntrichia ruralis subsp. ruralis a jellemző faj. A Marchantia polymorpha subsp. ruderalis nagy telepben nő az intézet betonvirágládáiban.

Egy különleges élőhely is kialakult a tó vízelvezető árkára épített vízimalom maradványainál. Az árkot mészkövekkel bélelték ki és a malom működtetése érdekében egy kis vízesést is létrehoztak. A hely hűvös, árnyékos és a mészkő jelenléte miatt eléggé speciális. Itt találtuk meg a vörös listás besorolás szerint veszélyeztetett Eurhynchium speciosum-ot, Amblystegium serpens, Brachythecium rutabulum, Leptodictyum riparium és Tortula muralis jelenlétében.

Az 1. táblázatban látható a parkban élő fajok elsődleges szubsztrát szerinti megoszlása. A területen elsősorban a talajon élő és epifiton fajok dominálnak.

1. táblázat. A parkban előforduló fajok megoszlása az aljzat szerint Table 1. Distribution of bryophyte species by substrate

\begin{tabular}{lc}
\hline \multicolumn{1}{c}{ Felszín / Substrate } & Fajok / Species \\
\hline Mesterséges / Man-made & 8 \\
Szikla / Rock & 5 \\
Korhadó fa / Decaying wood & 1 \\
Talaj / Soil & 24 \\
Fakéreg / Tree bark & 18 \\
\hline Összes / Total & 56 \\
\hline
\end{tabular}




\section{A parkban előforduló mohák felsorolása}

A parkban talált fajok felsorolása alfabetikus sorrendben történik külön választva a májmohákat és a lombosmohákat. Az auctor-név után zárójelben szerepel a fajok veszélyeztetettségi besorolásának rövidítése a magyar moha vörös lista szerint (PAPP et al. 2010). A kategóriák a következőek: EN - veszélyeztetett (kevesebb mint hat ismert aktuális élőhely, magas a kihalás veszélye), VU - sérülékeny faj (hat-tíz ismert élőhely, magas a kihalás veszélye), NT veszélyeztetettséghez közeli (több mint tíz ismert populáció, de azok kisméretűek vagy az élőhely veszélyeztetett), LC - közönséges, nem veszélyeztetett faj, LC-att - közönséges, de figyelmet érdemlő, legtöbbször indikátor faj. Ezt követi a faj parkon belüli gyakoriságának, valamint élőhelyének jellemzése. Végül pedig a faj magyarországi elterjedése, élőhelyi jellemzői kerülnek ismertetésre ORBÁN \& VAJDA (1983) munkája alapján, adott esetekben kiegészítve újabb megfigyelésekkel.

\section{Hepaticophytina}

Lophocolea heterophylla (Schrad.) Dumort. (LC) Ritka. Egyetlen helyen találtuk meg a park területének erdős részén egy korhadó fán. Magyarországon nem ritka faj. Középhegységekben gyakori, de az Alföldön is előfordul.

Marchantia polymorpha subsp. ruderalis Bischl. et Boisselier (LC) Gyakori faj. A park nedves, csupasz talajfelszínein, úgy mint a szántóföldeken, beton virágtartók virágföldjén, megtalálható tömegesen. Utóbbi élőhelyén rendszeresen irtják is gyomirtóval, de újra és újra megjelenik. Magyarországon gyakori faj a Dunántúlon.

Metzgeria furcata (L.) Dumort. (LC) Ritka. Egyetlen helyen találtuk meg a ligeterdő belsejében egy öreg kőris törzsének északi oldalán. Magyarországon a hegy és dombvidékeken gyakori, Alföldön ritka.

Porella platyphylla (L.) Pfeiff. (LC) Gyakori. A park erdős részén néhány a fák törzsén találtuk meg. Magyarországon elterjedt, gyakori faj.

Radula complanata (L.) Dumort. (LC) Ritka. A park erdős részén és néhány magányosan álló fán is megtaláltuk ezt a fakérgen élő fajt. Magyarországon gyakori.

Riccia cavernosa Hoffm. emend. Raddi. (NT) Ritka. Egy példánya került elő az üvegházban, virágföldön. Valószínűleg a Zala megyéből származó virágfölddel került be és hajtott ki. Jelenléte feltételezhetően csak ideiglenes, mert nem áll rendelkezésre megfelelő állandó környezet. A vörös lista szerint veszélyeztetettséghez közel álló faj. Folyóparti iszapon, kiszáradó pocsolyákban, nedves helyeken él.

\section{Bryophytina}

Amblystegium serpens (Hedw.) Schimp. (LC) Gyakori. Talajon, fákon egyaránt megtalálható. Országosan is elterjedt, gyakori faj.

Aphanorrhegma patens (Hedw.) Lindb. (NT) Ritka. A szántóföldi területek árnyékosabb, nedves szegélyében találtuk meg nyílt talajfelületen. Nedves, iszapos élőhelyen élő faj, folyóparton, pocsolyákban. A vörös listás besorolás szerint veszélyeztetettséghez közel áll. Országosan gyakori faj.

Barbula convoluta Hedw. (LC) Gyakori. A park szinte bármely területén megtalálható a talajfelszínen, legyen az betonrepedés, szántóföldi talaj, vagy erdei ösvény, fák töve. Az egész országban elterjedt faj, löszös, agyagos, meszes, homoktalajon is megél.

Barbula unguiculata Hedw. (LC) Gyakori. Szántóföldi szegélyen, utak mellett fák tövén, erdei ösvény. Országosan is elterjedt, homokos, agyagos talajon él. 
Brachythecium rutabulum (Hedw.) Schimp. (LC) Nagyon gyakori. Erdőben fákon, árnyékos helyeken a talajon, de vascsöveken is megtaláltuk. Egyes helyeken összefüggő gyepeket alkot. Országosan is elterjedt, eutrofizációt mutató faj. Erdőkben, patakmedrekben, sziklákon, fák tövén gyakori.

Brachythecium salebrosum (F. Weber et D. Mohr) Schimp. (LC) Gyakori. Erdőben fák kérgén, korhadó fán. Országosan is gyakori erdei faj.

Bryoerythrophyllum recurvirostrum (Hedw.) P.C. Chen (LC-att) Ritka. Egy helyen találtuk meg a kastély mészkőhídján Pseudocrossidium revolutum gyepében. Árnyékos, mészköves élőhelynek az indikátorfaja. Országosan a hegyvidékeken gyakori sziklai faj, de az Alföldön ritka.

Bryum argenteum Hedw. (LC) Nagyon gyakori. Beton felületeken, fák tövén, különböző talajokon megtalálható (szántóföldön, kikopott gyepben, virágládákban). Országosan is nagyon közönséges, erősen nitrofil faj.

Bryum caespiticium Hedw. (LC) Ritka. Kőhídon találtuk meg. Országosan gyakori faj, a kitett, száraz élőhelyeket kedveli, köveken, talajon egyaránt előfordul.

Bryum capillare Hedw. (LC) Ritka. Fák tövén, talajon találtuk meg. Az egész országban elterjedt, gyakori faj. Árnyékos helyeken erdőkben, élő és korhadó fákon, talajon él.

Bryum moravicum Podp. (LC) Gyakori. Fák kérgén találtuk meg. Magyarországon az erdős helyeken elterjedt. Árnyékos helyeken, erdőkben, főleg fák kérgén, de sziklán, köveken és betonon is él (ERZBERGER \& SCHRÖDER 2013).

Calliergonella cuspidata (Hedw.) Loeske (LC) Gyakori. A park nyírt gyepében találtuk meg tenyérnyi gyepjeit. Középhegységekben, dombságokon gyakori, Alföldön ritkább. Eutrofizációt jelző indikátor faj. A nedves élőhelyeket kedveli (láprétek, árkok, patakok mellett).

Ceratodon purpureus (Hedw.) Brid. (LC) Nagyon gyakori. Járdák, utak mellett a talajon szinte mindenhol előfordul. Az országban is nagyon gyakori. Száraz, napos helyeken és mészben szegény talajon, a legkülönfélébb aljzatokon.

Dicranoweisia cirrata (Hedw.) Lindb. ex Milde (LC-att) Ritka. Néhány fa kérgén találtuk meg. Magyarországon gyakori, régebben hegyvidéki fajként tartották számon, de mai ismereteink alapján az Alföldön is elterjedt epifiton faj. Vörös listás besorolás szerint figyelmet érdemlő kéreglakó indikátor faj.

Drepanocladus aduncus (Hedw.) Warnst. (LC) Ritka. A Vöröskúti-rét nedves talaján a gyepben találtuk meg ezt a fajt. Magyarországon nagyon gyakori, nedves réteken él.

Eurhynchium hians (Hedw.) Sande Lac. (LC) Gyakori. Nedves talajon, gyepben sok helyen előfordul a parkban. Az országban is nagyon gyakori.

Eurhynchium speciosum (Brid.) Jur. (EN) Ritka. Egy helyen találtuk meg, a volt vízimalom maradványainál, a mészkővel kirakott patakmederben $\left(\mathrm{N} 47.31350^{\circ}, \mathrm{E} 18.78168^{\circ}, 110 \mathrm{~m}\right.$ t.sz.f. magasság, 2015.10.17. leg. et det. P. Erzberger, B-Erzberger 20861, conf. W. Schröder). Herbáriumi adatok alapján a magyarországi vörös listán veszélyeztetett besorolást kapott ez a faj, 1990 után csak hét ismert élőhelyéről tudunk. Meszes forrásoknál, patakoknál, hévizeknél, kutakban él.

Fissidens taxifolius Hedw. (LC) Ritka. Két helyen találtuk meg a parkban nedves talajon. Az országban gyakori. Árnyékos agyagtalajokon él erdőkben, parkokban.

Funaria hygrometrica Hedw. (LC) Ritka. Elvétve fordul elő a park területén nedvesebb, árnyékos, hamuval borított talajon. Kozmopolita, az országban mindenütt elterjedt, gyakori faj, nitrogénben gazdag talajokon mindenütt előfordul.

Grimmia pulvinata (Hedw.) Sm. (LC) Nagyon gyakori. Szinte minden betonfelületen, tetőcserépen, kőszobrokon, kőfelületen megtalálható. Magyarországon is gyakori kozmopolita faj, betonon, szilikátos, meszes kőfelületen egyaránt előfordul.

Homalothecium lutescens (Hedw.) H. Rob. (LC) Ritka. A pince melletti fenyőfa alatti gyepben találtuk meg. Magyarországon gyakori. Napos, száraz helyeken él lösz- és homoktalajon.

Homalothecium sericeum (Hedw.) Schimp. (LC) Gyakori. A ligeterdő fáinak a kérgén találtuk 
meg. Magyarországon a hegységekben gyakoribb, Alföldön ritkább, köveken, fakérgen él.

Hypnum cupressiforme Hedw. (LC) Nagyon gyakori. Betonon, köveken, fák tövén szinte mindenhol megtalálható a park egész területén. Magyarországon is gyakori. Kozmopolita, mindenféle aljzaton előfordul, sokszor tömeges.

Leptodictyum riparium (Hedw.) Warnst. (LC) Ritka. A kiszáradt, köves patak mederben találtuk meg. Magyarországon gyakori, nedves élőhelyeken él fóként völgyekben, síkságokon.

Leskea polycarpa Ehrh. ex. Hedw. (LC) Nagyon gyakori. Útmenti, erdőszéli fák törzsén szinte mindig megtalálható ez a polikarp faj. Magyarországon is elterjedt. Nedves, vízközeli, eutróf élőhelyek epifiton növénye.

Leucodon sciuroides (Hedw.) Schwägr. (LC) Ritka. A ligeterdőben találtuk meg néhány fán. Magyarországon gyakori erdei faj a szárazabb erdőtársulásokban, főleg tölgyesekre jellemző.

Orthotrichum affine Schrad. ex Brid. (LC) Gyakori. A park bármely részén megtalálható ahol fák nőnek. Magyarországon is elterjedt ez a kéreglakó faj.

Orthotrichum anomalum Hedw. (LC) Gyakori. Beton felületeken, tetőcserepeken, köveken található. Az országban gyakori, de inkább hegyvidékre jellemző faj, az Alföldön ritka.

Orthotrichum cupulatum Brid. (LC-att) Ritka. Néhány mészkövön találtuk meg. Magyarországon a hegységekben gyakori, az Alföldön ritka. A vörös listás besorolás szerint gyakori, de figyelmet érdemlő faj, sziklai indikátor.

Orthotrichum diaphanum Schrad. ex Brid. (LC) Nagyon gyakori. Beton felületeken, tetőcserepeken, köveken, szobrokon megtalálható egyaránt. Magyarországon is gyakori, eutrofizációra utaló faj, főleg fakérgen él.

Orthotrichum obtusifolium Brid. (NT) Ritka. Egy helyen találtuk meg egy kivágott kőrisfa kérgén, Orthotrichum affine mellett. Kéreglakó indikátor faj, a vörös listás besorolás szerint veszélyeztetettséghez közel áll, de az újabb megfigyelések (Erzberger és munkatársai, ined.) szerint gyakoribb, talán terjedő.

Orthotrichum pallens Bruch ex Brid. (LC) Ritka. A ligeterdő fáin találtuk meg. Az ország egész területén előforduló de nem gyakori, nyílt erdőkben élő kéreglakó faj.

Orthotrichum patens Bruch ex Brid. (VU) Ritka. Néhány helyen találtuk meg a ligeterdő fáin. A vörös lista szerint veszélyeztetett besorolású epifiton faj, de az elmúlt évek vizsgálatai azt mutatják, hogy ez a besorolás nem indokolt (Erzberger és munkatársai, ined.).

Orthotrichum pumilum Sw. (NT) Ritka. Néhány helyen találtuk meg a ligeterdő fáin. A vörös lista szerint veszélyeztetettséghez közelálló epifiton indikátor faj, de az elmúlt évek vizsgálatai azt mutatják, hogy ez a besorolás nem indokolt (Erzberger és munkatársai, ined.).

Orthotrichum speciosum Nees (LC-att) Gyakori. A ligeterdő fáin található gyakori faj. Országosan is gyakori, de figyelmet érdemlő epifiton indikátor faj.

Phascum cuspidatum Hedw. (LC) Gyakori. A szántóföldek szélén a nedves talajon találtuk. Országosan is gyakori nyílt gyepeken, szántóföldeken agyagos, löszös és homokos talajon.

Physcomitrium pyriforme (Hedw.) Brid. (LC) Ritka. Erdő szegélyében, nedves talajon találtuk meg egy helyen. Magyarországon gyakori. Iszapos, nedves agyagos, homokos talajon él (árkok, tarlók).

Plagiomnium affine (Blandow) T.J. Kop. (LC) Ritka. Néhány helyen találtuk meg a park nyírt, árnyékos gyepes területén. Országosan gyakori, erdőkben, útbevágásokban élő talajlakó.

Plagiomnium cuspidatum (Hedw.) T.J. Kop. (LC) Gyakori. A park árnyékos füves gyepében, de Brachythecium rutabulum gyepében is megtaláltuk. Magyarországon is gyakori, nedves, árnyékos talajon, fakérgen, köveken él.

Plagiomnium undulatum (Hedw.) T.J. Kop. (LC) Ritka. Árnyékos füves gyepben találtuk meg egy helyen. Országosan gyakori, nedves, árnyékos talajokon él hegy- és síkvidéken.

Platygyrium repens (Brid.) Schimp. (LC) Gyakori. A ligeterdő fáin találtuk meg. Országosan is gyakori epifiton faj.

Pohlia melanodon (Brid.) A.J. Shaw. (LC) Gyakori. Szántóföldek mezsgyéjén, nyílt, nedves 
talajon találtuk meg. Országosan gyakori, nedves homokos-agyagos helyeken, árkokban, folyók, patakok mentén él.

Pottia truncata (Hedw.) Bruch et Schimp. (LC) Gyakori. Mészkőzúzalékkal borított helyeken, virágágyás szélén csupasz talajon találtuk meg. Országosan gyakori, nedves, félárnyékos agyagtalajon él.

Pseudocrossidium revolutum (Brid.) R.H. Zander (NT) Ritka. Csak a mészkőhídon találtuk meg de itt összefüggő nagyobb gyepeket alkot. Országosan ritka, a vörös listás besorolás szerint veszélyeztetettséghez közelálló faj. Hegyvidékeken, meszes sziklákon él.

Schistidium crassipilum H.H. Blom (LC) Ritka. Betonon, sziklákon találtuk meg. Országosan gyakori, mésztartalmú sziklákon, betonon, falakon él (ERZBERGER \& SCHRÖDER 2008).

Syntrichia papillosa (Wilson) Jur. (LC-att) Gyakori. Magányosan álló fák kérgén, tövén találtuk meg. Országosan is gyakori epifiton indikátor faj.

Syntrichia ruralis (Hedw.) F. Weber \& D. Mohr (LC) Nagyon gyakori. Cserép és azbeszt tetőkön az egész park területén gyakori. Országosan is elterjedt kozmopolita faj.

Syntrichia virescens (De Not.) Ochyra (LC-att) Ritka. Magányos fák kérgén és tövén él. Országosan gyakori. Ligeterdőkben, magányos fákon élő kéreglakó.

Thuidium philibertii Limpr. (LC-att) Ritka. Egy helyen találtuk meg a park nyírt, árnyékos, füves gyepében. Országosan gyakori, meszes, árnyékos, nyirkos talajokon él.

Tortula muralis L. ex. Hedw. (LC) Nagyon gyakori. Beton felületeken, falakon, tetőcserépen, köveken mindenütt megtalálható. Magyarországon is gyakori köveken, betonon élő pionír faj.

\section{Köszönetnyilvánítás}

Köszönet Papp Beátának, a Magyar Természettudományi Múzeum munkatársának, a Növénytár mohagyűjteményének gyújteményvezetőjének a szakmai segítségért és a rendelkezésre bocsátott adatokért, Ódor Péternek és Szűcs Péternek a kézirat lektorálásáért és szakmai segítségükért, továbbá Wiebke Schrödernek (Ludwigsstadt, Németország) az E. speciosum határozásának megerősítéséért.

\section{Irodalom}

ÁdÁM L., MARosi S. \& SzILÁRd J. (1959): A Mezőföld Természeti Földrajza. - Földrajzi Monográfiák II., Akadémiai Kiadó, Budapest, 514 pp.

BoRHIDI A. \& KEVEY B. (1996): An annotated checklist of the hungarian plant communities II. - In: BoRHIDI A. (ed.), Critical revision of the hungarian plant communities. Janus Pannonius University, Pécs, pp. 95-138.

Boros Á. (1915-1971): Florisztikai jegyzetek. [Field diaries.] - Manuscript, Hungarian Natural History Museum, Budapest.

Casas C., Brugués M., Cros R. M., SÉrgio C. \& Infante M. (2009): Handbook of Liverworts and Hornworts of the Iberian Peninsula and the Balearic Islands. - Institut d'Estudis Catalans, Barcelona.

Casas C., Brugués M., Cros R. M., Sérgio C. \& Infante M. (2006): Handbook of Mosses of the Iberian Peninsula and the Balearic Islands. - Institut d'Estudis Catalans, Barcelona.

ERZBERGER P. \& SCHRÖDER W. (2008): The genus Schistidium (Grimmiaceae, Musci) in Hungary. - Studia botanica hungarica 39: 27-88.

Erzberger P. \& Schröder W. (2013): The genus Bryum (Bryaceae, Musci) in Hungary. - Studia botanica hungarica 44: 5-192.

Galambos I. (1992): A Zirci Arborétum mohaflórája. - Folia Musei Historico-naturalis Bakonyiensis 11: 29-35.

Hill M.O., Bell N., Bruggeman-Nannenga M.A., Brugués M., Cano M.J., Enroth J., Flatberg K.I., Frahm J.-P., Gallego M.T., Garilleti R., Guerra J., Hedenäs L., Holyoak D.T., Hyvönen J., Ignatov M.S., Lara F., MAZIMPAKA V., MUNOZ J. \& SÖDERSTRÖM L. (2006): An annotated checklist of the mosses of Europe and Macaronesia. - Journal of Bryology 28: 198-267.

IGMÁNDY J. (1949): Adatok Sopron mohaflórájához. - Erdészeti kísérletek 49 (1-4): 164-167. 
Kevey B. (1979): Az Allium ursinum L. Magyarországi elterjedése. - Botanikai Közlemények 65: 165-175. KEvEY B. (1987): A martonvásári kastélypark tölgy-kőris-szil ligeterdői. - Botanikai Közlemények 73 (1-2): $33-42$.

Kevey B., Majláth I. \& MolnáR M. (2016): Changes in the hardwood groves of the Martonvásár Manor Park (Hungary) in the last 30 years. - Acta Botanica Hungarica 58 (3-4): 265-286.

MANNINGER I. (1989): Botanikai érdekességek, hírneves botanikusok Martonvásáron. - Az MTA Mezőgazdasági Kutatóintézetének és Kísérleti Gazdaságának Közleményei 89 (2): 13-14.

ORBÁN S. \& VAJDA L. (1983): Magyarország mohaflórájának kézikönyve. - Akadémiai Kiadó, Budapest.

PAPp B., ERZberger P., Ódor P., Hock Zs., SzÖvÉnYI P., SzuRdoki E. \& Tóth Z. (2010): Updated checklist and red list of Hungarian bryophytes. - Studia botanica hungarica 41: 31-59.

PÓKA M. (1978): A Martonvásári Park. - Búvár 33: 377.

QGIS Development TeAm (2014): QGIS GeographicInformation System. - Open Source Geospatial Foundation Project. http://qgis.org

Sмiтн A. J. E. (2004): The mossflora of Britain and Ireland. - Cambridge University Press, Cambridge.

SzúCS P. (2008): Bryofloristic studies in Botanic Garden in Sopron. - Kitaibelia 13 (1): 193. [poster at the $8^{\text {th }}$ recent floristic and vegetaion research Conference]

Szû́cs P. (2009): Mohaadatok az Agostyáni Arborétumból. - Komárom-Esztergom Megyei Múzeumok Közleményei 15: 159-164.

SzŰ́cS P. (2013): Kiegészítések a Zirci Arborétum mohaflórájához. - Folia Musei Historico-naturalis Bakonyiensis 30: 47-54.

VAjDa L. (1954): A Vácrátóti Botanikai Kutató Intézet Természetvédelmi Parkjának mohái. [Die Moose im Naturschutzparke des Botanischen Forschungsinstitutes von Vácrátót.] - Botanikai Közlemények 45: 63-66.

VAJDA L. (1968): A Szigligeti Arborétum mohái. [Die Moose des Arboretums Szigliget.] - A Veszprém megyei múzeumok közleményei 7: 237-240.

Beérkezett / received: 2016. 07. 22. • Elfogadva / accepted: 2016. 08. 23. 